\title{
Occurrence and assemblage composition of intertidal non-native species may be influenced by shipping patterns and artificial structures
}

\author{
Kathryn A. O'Shaughnessy ${ }^{\mathrm{a}, *}$, Stephen J. Hawkins ${ }^{\mathrm{b}, \mathrm{c}, \mathrm{e}}$, Anna L.E. Yunnie ${ }^{\mathrm{d}}$, Mick E. Hanley, \\ Paul Lunt ${ }^{\mathrm{a}}$, Richard C. Thompson ${ }^{\mathrm{e}}$, Louise B. Firth ${ }^{\mathrm{e}}$

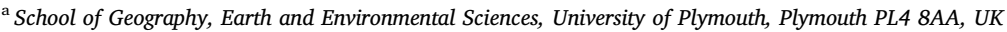 \\ ${ }^{\mathrm{b}}$ Ocean and Earth Science, University of Southampton, National Oceanography Centre Southampton, Southampton SO17 3ZH, UK \\ c The Marine Biological Association of the UK, The Laboratory, Citadel Hill, Plymouth PL1 2PB, UK \\ ${ }^{\mathrm{d}}$ PML Applications Ltd, Plymouth Marine Laboratory, Plymouth PL1 3DH, UK \\ ${ }^{\mathrm{e}}$ School of Biological and Marine Sciences, University of Plymouth, Plymouth PL4 8AA, UK
}

\section{A R T I C L E I N F O}

\section{Keywords:}

Invasive species

Non-indigenous species

Biodiversity

Biological invasion

Ocean sprawl

Rapid Assessment Surveys

\begin{abstract}
A B S T R A C T
Habitat modification coupled with the spread of non-native species (NNS) are among the top threats to marine biodiversity globally. Species are known to be transported to new locations via international shipping and secondarily spread via regional vessels and artificial structures. Rapid Assessment Surveys (RAS) combining quantitative and semi-quantitative methods compared NNS richness and assemblage composition on intertidal natural rocky shores and artificial structures in harbours in different regions along the south coast of England. Quantitative data showed that artificial habitats supported higher richness than natural habitats, while semiquantitative data found no difference in richness among habitat types. This result was attributed to additional species found in rock pools during searches of complex microhabitats in natural habitats. Assemblages on artificial structures differed among regions, with regions and harbours with greater numbers of vessels supporting greater richness. Results highlight the importance of shipping and artificial structures for NNS introduction and spread.
\end{abstract}

\section{Introduction}

Habitat modification and the introduction and spread of non-native species (NNS) are impacting natural ecosystems and threatening global biodiversity (Manchester and Bullock, 2000; Bax et al., 2003; Simberloff, 2005). In marine coastal systems, "ocean sprawl" (sensu Duarte et al., 2012) - the proliferation of artificial structures (e.g., seawalls, groynes, piers, floating pontoons, offshore platforms) - is replacing natural habitats with a variety of hard engineered structures built to support human activities (e.g., aquaculture, transportation, industry, shipping, energy extraction), as well as stabilise and protect shorelines from rising and stormier seas (Griggs, 2005; Duarte et al., 2012; Firth et al., 2016a; Bishop et al., 2017). Artificial structures provide new 'competitor-free' habitat for NNS settlement and establishment (Airoldi and Bulleri, 2011; Firth et al., in review), as well as increase ecological connectivity between local and global shipping hubs (Floerl et al., 2009; Airoldi et al., 2015). These novel habitats enable the spread of cryptogenic (i.e., it is unclear whether the species is native or introduced; Kinzie, 1984; Carlton, 1996a), opportunistic (i.e., a species adapted to exploit new or disturbed habitats; Whitlatch and Zajac, 1985) and non-native species (Ruiz et al., 1997; Dafforn et al., 2009; Firth et al., 2016a). Artificial structures also facilitate the homogenisation of biological communities, supporting novel species assemblages not encountered in natural habitats, and affect the structure and functioning (physical and ecological) of the surrounding environment (McKinney and Lockwood, 1999; McKinney, 2006; Dugan et al., 2011).

The rise in global trade has meant that harbours are characterised by a range of artificial structures, with an extraordinary amount of shipping traffic arriving from ports across the globe every day (Seebens et al., 2013; Marine Traffic, 2019; World Port Source, 2019). These mobile vectors (ranging from small, local leisure craft to large intercontinental commercial tankers) are able to spread NNS among the proliferating static structures (i.e., seawalls, breakwaters, groynes, floating pontoons) in destination ports such that the latter act as species reservoirs (Ruiz et al., 1997; Neves et al., 2007; Clarke Murray et al., 2011; Mineur et al., 2012). At a global scale, the primary vectors of initial introduction are typically transoceanic ships, barges and floating platforms (i.e., mobile vectors) that dock in large international

\footnotetext{
* Corresponding author.

E-mail addresses: kathryn.oshaughnessy@plymouth.ac.uk, oshaug3@gmail.com (K.A. O'Shaughnessy).
} 
harbours (Carlton and Geller, 1993; Ruiz et al., 1997; Molnar et al., 2008). These vessels transport species in two main ways: (1) as larvae in ship ballast water (Ruiz et al., 1997; Gollasch, 2008) and (2) as adults fouling ship hulls (Gollasch, 2002; Drake and Lodge, 2007). Thus, initial NNS colonisation and settlement tend to be highest within major shipping ports compared to surrounding areas (Eno et al., 1997; Molnar et al., 2008; Keller et al., 2011). Secondary, local spread of NNS is then probably through a combination of small mobile vectors (fishing and leisure craft) to nearby artificial structures (Clarke Murray et al., 2011; Mineur et al., 2012; Airoldi et al., 2015). Planktonic larvae can also be carried away from the port of introduction by wave-driven currents (McQuaid and Phillips, 2000), settling on artificial structures along the coast (McQuaid and Phillips, 2000; Wasson et al., 2001). In this way, artificial structures can act as stepping stones, allowing non-natives to persist or spread by provision of 'virgin' hard substrate among otherwise uninhabitable habitats (e.g., 'soft bottom' sediment habitat; Apte et al., 2000; Sammarco, 2015; Airoldi et al., 2015).

The biological communities of artificial structures are typically less diverse, and support greater numbers of NNS, than comparable, nearby natural rocky shore habitats (Glasby et al., 2007; Vaselli et al., 2008; Dafforn et al., 2015a). This disparity is attributed to the physical design of artificial structures; they typically have steep profiles and reduced surface area and limited topographic complexity compared to their natural analogues (Moschella et al., 2005; Chapman and Underwood, 2011). The disturbance associated with human activities in harbours can also physically dislodge organisms and create space for new colonisers to exploit, thereby influencing successional dynamics of the community (e.g., removal of predators, loss of canopy algae; Stachowicz et al., 1999; Byers, 2002). Additionally, ports are usually located within sheltered bays or estuaries, which by nature, experience greater fluctuations in temperature and salinity (Whitehead et al., 2009), input of nutrients (Statham, 2012) and other pollutants (Stark, 1998; Johnston et al., 2017; Hitchcock and Mitrovic, 2019) compared to open coasts. More importantly, many non-natives are generalist species that often have longer planktonic larval durations or extended reproductive seasons (Dineen et al., 2001; Muxagata et al., 2004), which means they are able to take advantage of bare space as it becomes available through creation of new substrate or after disturbance events. For example, in the UK, the non-native barnacle, Austrominius modestus (Darwin, 1854), is reproductive almost year-round (Muxagata et al., 2004), while native barnacle species reproduce mainly in the spring (e.g., Semibalanus balanoides (Linnaeus, 1767)) or summer (e.g., Chthamalus montagui Southward, 1976 and C. stellatus (Poli, 1791); Burrows et al., 1992). These physical and biological factors probably interact, leaving severely disturbed areas vulnerable to more resilient and opportunistic invaders (Stachowicz et al., 1999; Airoldi and Bulleri, 2011; Johnston et al., 2017).

It is important to understand the practically synergistic interaction between ocean sprawl and global shipping so that potential introduction points can be predicted and appropriate invasive species forecasting techniques can be developed. Yet to our knowledge, we know of no studies that explored the influence of shipping patterns on occurrence of NNS in intertidal habitats along the south coast of England (an area historically known as a point of introduction to the British Isles; for a review of potential sources of NNS introduction into the British Isles see Eno et al. (1997)). Even less attention has focussed on understanding differences in NNS occurrence and assemblage compositions between natural and artificial intertidal habitats (but see Glasby et al., 2007; Dafforn et al., 2012; Dafforn et al., 2015a for natural and artificial comparison in subtidal habitats). Information from natural habitats may be useful in determining the potential for NNS to spread out from points of initial introduction (Valentine et al., 2007; Carman and Grunden, 2010; Epstein and Smale, 2018). Understanding the mechanisms underpinning the differences in NNS occurrence between natural and artificial habitats is also critical to develop a robust foundation of evidence upon which to base ecological engineering (i.e., the combination of ecological and engineering design to create sustainable ecosystems that benefit humans and nature; Mitsch and Jørgensen, 2003; Odum and Odum, 2003). To address the current knowledge gaps concerning occurrence of NNS on natural rocky shores and artificial structures in intertidal habitats, we conducted surveys of NNS in intertidal natural and artificial sites in 11 harbours along the south coast of England to test the following hypotheses:

1. NNS richness would be greater, and NNS assemblage composition would differ, in artificial compared to natural habitats.

2. NNS richness and NNS assemblage composition in artificial habitats would differ among harbours and regions, but would be highest in ports with higher number of arriving vessels.

Our study also provided the opportunity to compare data obtained from quantitative stratified-random quadrat-based surveys with semiquantitative methods based on timed searches, as both approaches were used here.

\section{Materials and methods}

\subsection{Study region}

The English Channel is one of the busiest waterways in the world (Marine Traffic, 2019; World Port Source, 2019). The coast along the English side of the Channel is characterised by a number of harbours that support international and regional shipping and cruise traffic, military traffic, ferries to continental Europe and recreational and tourist activities (Table 1). Consequently, the south coast of England has traditionally been susceptible to invasions and is known as the point of introduction into the British Isles for many NNS from Europe and around the world (Eno et al., 1997; Bishop et al., 2015a; Bishop et al., 2015b). In this study, harbours were grouped into geographic regions following Bishop et al. (2015b) (West, Central, East; Table 1, Fig. 1). One survey was done per site (hereafter referred to as 'site'), and sites were located either within natural (rocky shores) or artificial (artificial structures) habitats. Numbers of sites surveyed per harbour varied and reflected the size of the harbour. All harbours had artificial substrata, but only harbours in the West had natural rocky shore (contained within the larger natural harbour) for comparison with artificial structures (for classification of harbours within regions see Table 1). The natural versus artificial habitat assessment involved only seawalls made from naturally-sourced rock for comparison to natural rocky shores. The comparison of NNS across all harbours along the south coast of England assessed multiple types of artificial structures, which included piers, marina wave-breaker walls, seawalls, discharge pipes, groynes, boat docks, bridge support structures, wharfs and breakwaters (Table S1). As artificial structures were opportunistically sampled, not all structure types were represented in each harbour. To compare richness and assemblage composition of artificial sites (artificial structures) among harbours and regions across the entire south coast of England, all artificial structures were used for analysis. The areas surveyed were at the mouths of any estuarine complexes and generally fully saline at high tides and thus comparable to non-estuarine ports (i.e., Torbay, Folkestone, Dover; Table S1).

\subsection{Sampling methods}

Rapid Assessment Surveys (RAS) provide a pragmatic method of covering a large number of locations in a reasonable amount of time (Pederson et al., 2005; Arenas et al., 2006; Bishop et al., 2015a, 2015b); they typically involve a qualitative approach, using timed searches of targeted areas and habitats (e.g., undersides of floating pontoons). In biodiversity surveys, however, the most common means of gathering data is predominantly through quantitative quadrat sampling, often avoiding topographically complex surfaces (Bulleri et al., 2005; Dafforn 


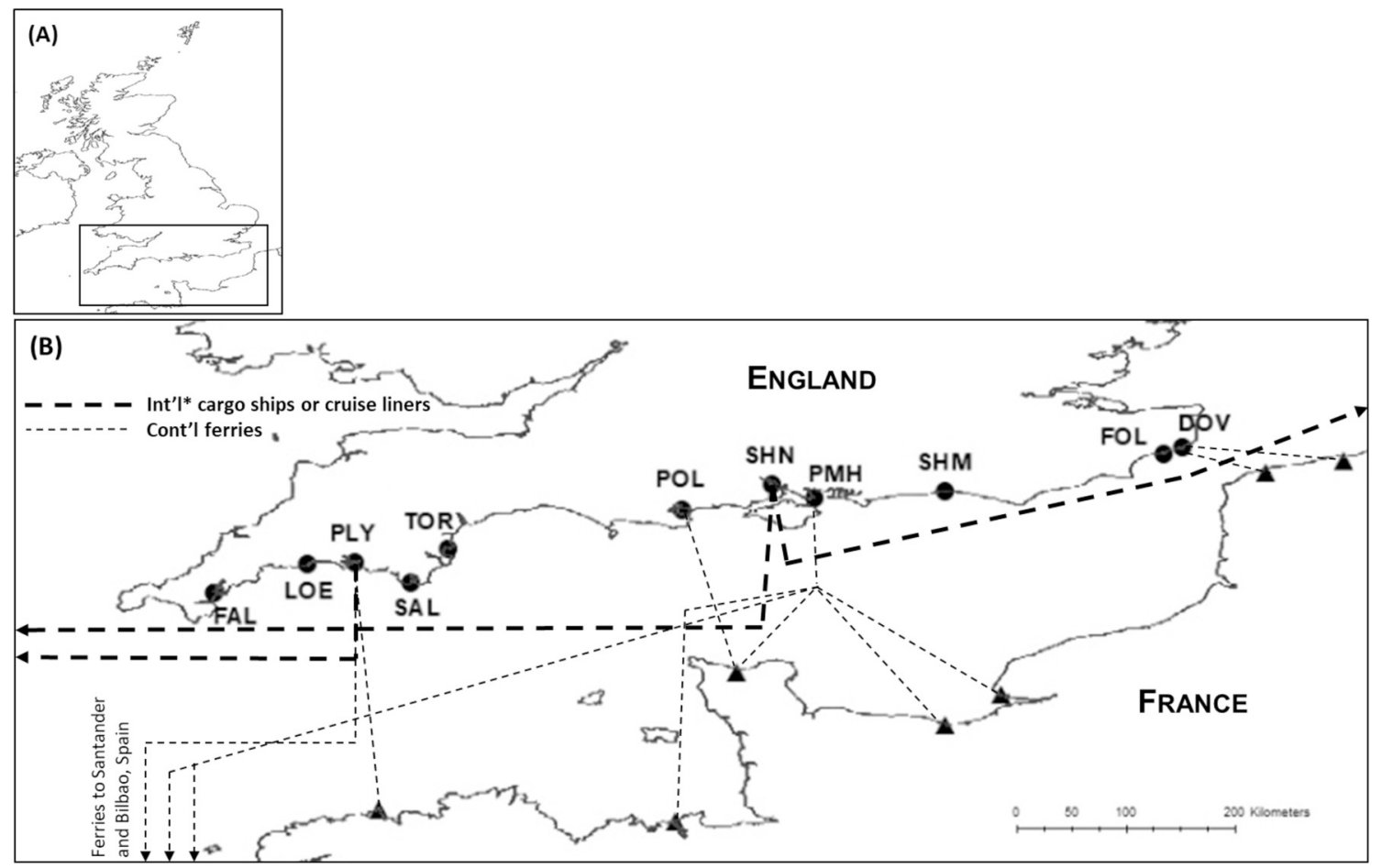

Fig. 1. (A) Map of the British Isles, with the English Channel indicated by the black box. (B) Continental ferry routes across the English Channel are shown by the light dashes and internationally sailing vessels (cargo ships or luxury cruise liners) are shown by the dark dashes. Lines representing shipping routes do not reflect the numbers of vessels arriving and departing. "International cargo ships and cruise liners include only those vessels that travel outside of northern Europe (e.g., Dover supports cargo-shipping activities, but these ships regularly sail only to European destinations). Southampton and Plymouth are the only harbours with ships that sail internationally on a regular basis (dark dashes). Harbours within the West region include Falmouth, Looe, Plymouth, Salcombe and Torbay, and were the only harbours included in the natural and artificial comparison. Harbours within the Central region include Poole, Southampton and Portsmouth. Harbours within the East region include Shoreham, Folkestone and Dover. Artificial structures in all harbours were included in analyses of richness and assemblage composition in artificial habitats. See Table 1 for Harbour codes. Information was obtained from Marine Traffic (2019) and World Port Source (2019).

et al., 2012; Firth et al., 2016b). In this study, a combined approach was employed to capture NNS richness and abundance (i.e., diversity), which consisted of utilising quantitative stratified-random quadrat sampling and semi-quantitative timed searches. All artificial structures were accessed on foot at low tide. Native biota were not quantified during any of the surveys. Quantitative stratified-random quadrat sampling involved haphazardly placing 20 quadrats $(25 \times 25 \mathrm{~cm})$ in the lower intertidal within a $10 \times 10 \mathrm{~m}$ area and recording counts of mobile organisms and percentage cover of sessile organisms. For the purpose of this study, the lower intertidal was the area of the shore that was inundated during neap low tides but exposed at spring low tides (i.e., surveys occurred only on spring low tides when tide was $\leq 1 \mathrm{~m}$ above $\mathrm{CD}$ ). Occasionally, this area was condensed because the steeper slope of artificial structures resulted in reduced area available to survey. In these cases, a longer horizontal section was sampled to compensate for lost vertical area. All NNS visible to the naked eye within the quadrats were identified and quantified. To positively identify and quantify the non-native barnacle, Austrominius modestus, $5 \times 5 \mathrm{~cm}$ photo-quadrat images $(n=20)$ were taken in the densest barnacle zone and photographs were later analysed using ImageJ (Schneider et al., 2012). Slope and substrate were standardised by surveying vertical or sloping substrate ( $\geq 45^{\circ}$ angle) and avoiding topographically complex surfaces (i.e., gaps, grooves, pits, crevices, rock pools). To locate rare species, one person conducted a 30-minute timed search across the study area, including complex surfaces and microhabitats (e.g., crevices, rock pools, undersides of boulders). Additional minutes were added to the search where logistical constraints delayed efficient sampling (e.g., some artificial structures had characteristics that required careful manoeuvring around the structure compared to other easily accessible structures or natural rocky shore). A semi-quantitative search-based assessment of overall abundance of each NNS was made on a scale of $0-3(0=$ absent, $1=$ rare-occasional, $2=$ frequentcommon, 3 = abundant-superabundant; Bishop et al., 2015b). Thus, the quantitative quadrat method produced 20 quadrat replicates per site, while the semi-quantitative search-based method produced one abundance score for each NNS per site. Species that could not be identified in the field (e.g., bryozoans such as Tricellaria inopinata (d'Hondt \& Occhipinti Ambrogi, 1985) and Bugulina spp.) were preserved in $70 \%$ ethanol and transported back to the laboratory for microscopic examination.

\subsubsection{Comparison of NNS in natural and artificial habitats}

To investigate differences of occurrence of NNS between natural and artificial habitats, NNS richness and assemblage composition were recorded in ten natural sites (rocky shores) and eleven artificial sites (seawalls) in the West region (Table 1). Natural sites were chosen based on location to closest harbour and were as sheltered as possible to reduce the influence of wave exposure gradients on assemblage composition. There was no restriction placed on size of seawall.

\subsubsection{Comparison of NNS in artificial habitats along the south coast of England}

To assess differences of occurrence of NNS in artificial habitats among harbours and regions, eleven harbours spanning three regions across the entire south coast of England were surveyed. Harbours within regions were chosen based on major harbours surveyed in Bishop et al. (2015b) and those which stretched across each region. As many artificial sites as possible with public access were surveyed in each harbour (Table 1). 


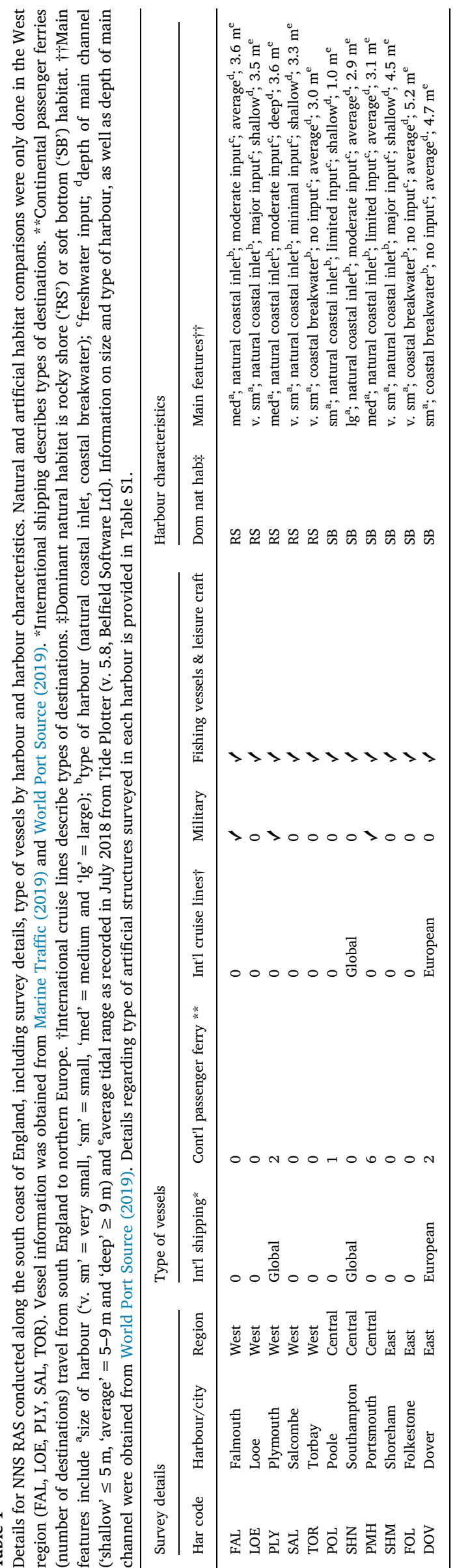

\subsection{Statistical analyses}

\subsubsection{Comparison of NNS in natural and artificial habitats}

To compare NNS richness and assemblage composition between natural and artificial habitats, comparisons were made between ten natural sites and eleven nearby artificial sites using both quantitative quadrat and semi-quantitative search-based data separately (i.e., data from both methods were used but were analysed separately). For both sampling methods, where abundance information was used, data were fourth-root transformed to down-weight the influence of very abundant species (Anderson et al., 2008). Bray-Curtis dissimilarly matrices were then computed, and permutational multivariate analysis of variance tests (PERMANOVA; Anderson, 2001) were used to test for differences in species richness and assemblage composition. Two-way nested designs with Habitat as a fixed factor (2 levels: natural, artificial) and Site as a random factor (nested in Habitat) were employed. PERMANOVA tests were based on 9999 permutations of residuals under a reduced model. Tests for differences were conducted in PRIMER v6 with the PERMANOVA + add-on using the PERMANOVA routine (PRIMER-E Ltd., Plymouth, UK; Anderson et al., 2008). Ordination of samples was visualised using two-dimensional non-metric multidimensional scaling (nMDS) plots. Contributions to dissimilarities among regions from each species was determined using the similarity percentages routine (SIMPER).

\subsubsection{Comparison of NNS in artificial habitats along the south coast of England}

Differences in NNS richness and assemblage composition in artificial habitats among harbours and regions were assessed using data from both the quantitative quadrat and semi-quantitative search-based surveys. Where abundance information was used, data were fourth-root transformed. Bray-Curtis dissimilarly matrices were then computed, and permutational multivariate analysis of variance tests (PERMANOVA) were used to test for differences in species richness and assemblage composition. For quantitative quadrat data, a three-way nested design was used for each test (species richness and assemblage composition) with Site as a random factor (number of levels depended on number of sites surveyed in each harbour) nested in Harbour as a fixed factor (number of levels varied with region) nested in Region as a fixed factor (3 levels: West, Central, East). As quantitative quadrat sampling was not undertaken in Salcombe, only ten harbours were included in quantitative quadrat analyses. Because there was not replication at the 'Site' level when semi-quantitative search-based data were analysed (i.e., there was one abundance value per site), two-way nested designs were used with Harbour as a fixed factor (number of levels varied with region) nested in Region as a fixed factor (3 levels) for each test (species richness and assemblage composition). Information about vessel type and the average number of vessels per harbour over a 60-day period as a proxy for boat traffic in general was obtained from the Marine Traffic (Marine Traffic, 2019) and World Port Source (World Port Source, 2019) websites. General observations comparing numbers of NNS with numbers and types of vessels were made with no formal analyses done.

\section{Results}

\subsection{Overall results}

A total of 26 NNS were recorded from natural and artificial habitats across the entire south coast of England (Table S1). Fifteen NNS were recorded from the natural and artificial habitat comparison in the West region (Falmouth to Torbay); 12 of these NNS were found in artificial, while 9 NNS were recorded in natural habitats (Table S1). Six species were exclusive to artificial habitats, while 3 species were exclusive to natural habitats, with 6 species common to both. Two NNS were discovered in new localities: colonies of the carpet sea squirt, Didemnum vexillum Kott, 2002, were found on the seaward side of a wooden wave- 
breaker wall and a metal pipe positioned perpendicular to the shore in Poole Harbour. Colonies were also found in Portsmouth on concrete fishing piers perpendicular to the shore. The red alga, Botryocladia wrightii (Harvey) W.E.Schmidt, D.L.Ballantine \& Fredericq, 2017 (recently changed from Chrysymenia wrightii), was found in a small waterretaining pool along a stepped seawall in Portsmouth. The only previously confirmed records of $B$. wrightii in this study region were from marinas in Falmouth (Wood et al., 2015).

\subsection{Comparison of NNS in natural and artificial habitats}

Of the 15 NNS recorded across natural and artificial habitats between Falmouth and Torbay (Table S1), 9 taxa were recorded in natural ( $60 \%$ of total), while 12 were observed in artificial ( $80 \%$ of total) habitats. Species unique to natural habitats included the brown alga, Undaria pinnatifida (Harvey) Suringar, 1873 and the red algae, Grateloupia turuturu Yamada, 1941 and Asparagopsis armata Harvey, 1855. Species unique to artificial habitats included the erect bryozoan, T. inopinata, the orange cloak sea squirt, Botrylloides violaceus Oka, 1927, an unidentified Botrylloides species, Botrylloides sp. indet. (Bishop et al., 2015b), the leathery sea squirt, Styela clava Herdman, 1881, the slipper limpet, Crepidula fornicata (Linnaeus, 1758) and the red alga, Bonnemaisonia hamifera Hariot, 1891. Semi-quantitative search-based techniques found 15 NNS across natural and artificial habitats, while quantitative quadrat techniques yielded only 8 species. The use of quantitative quadrat techniques alone failed to record $B$. violaceus, $C$. fornicata, U. pinnatifida, G. turuturu, A. armata, B. hamifera and the brown alga, Sargassum muticum (Yendo) Fensholt, 1955.

Statistical analysis of quantitative quadrat data found that mean NNS richness was significantly greater in artificial compared to natural habitats (Table 2a; Fig. 2a). Similarly, assemblage composition varied significantly between natural and artificial habitats (Table 2a). Statistical analysis of semi-quantitative search-based data revealed that the mean richness did not differ significantly between natural and artificial habitats, although community assemblage did differ (Table 2b; Fig. 2b, c). SIMPER analysis of quantitative quadrat data showed that over $80 \%$ of dissimilarity in assemblage composition between natural and artificial habitats was attributed to A. modestus $(32.6 \%)$, the red ripple bryozoan, Watersipora subatra (Ortmann, 1890) (30.9\%) and the red alga, Caulacanthus okamurae Yamada, 1933 (23.1\%), with all three species more abundant in artificial habitats. SIMPER analysis of semiquantitative data revealed that $>50 \%$ of dissimilarity in assemblage composition between natural and artificial habitats was attributable to four species: S. muticum (17.3\%), W. subatra (14.5\%), the brown alga, Colpomenia peregrina Sauvageau, 1927 (12.4\%) and the Pacific oyster, Magallana gigas (Thunberg, 1793) (11.8\%). S. muticum and C. peregrina were more abundant in natural habitats, while W. subatra and M. gigas were more common in artificial habitats.

\subsection{Comparison of NNS in artificial habitats along the south coast of England}

Overall, 26 NNS were recorded in artificial sites across eleven harbours. The barnacle, A. modestus, was encountered most (43 sites), while the erect bryozoan, Bugulina simplex (Hincks, 1886), the orangetipped sea squirt, Corella eumyota Traustedt, 1882, B. wrightii, the green alga, Codium fragile subsp. fragile (Suringar) Hariot, 1889 and $U$. pinnatifida were only found at a single site each. Results are reported from both sampling methods, but only semi-quantitative search-based data were used to produce figures because this method captured more NNS overall.

Statistical analysis of quantitative quadrat data revealed that mean richness and assemblage composition were significantly different among harbours and regions (Table $3 \mathrm{a}$ ), with the Central region supporting greater mean and total richness than the West $(p=0.0222)$ and East regions $(p=0.0039)$. Pairwise comparisons among harbours
Table 2

PERMANOVA results comparing NNS richness and assemblage composition between natural and artificial habitats using (a) quantitative quadrat data and (b) semi-quantitative search-based data. Significant $p$-values are in bold.

\begin{tabular}{|c|c|c|c|c|c|}
\hline \multicolumn{6}{|c|}{ (a) Quantitative data } \\
\hline \multicolumn{6}{|c|}{$\begin{array}{l}\text { Two-way PERMANOVA comparing species richness between natural and artificial } \\
\text { habitats. }\end{array}$} \\
\hline Source & df & SS & MS & Pseudo-F & $\mathrm{P}($ perm $)$ \\
\hline Habitat & 1 & 18976 & 18976 & 7.1199 & 0.0009 \\
\hline Site(Habitat) & 18 & 47985 & 2665.8 & 33.327 & 0.0001 \\
\hline Residual & 380 & 30396 & 79.989 & & \\
\hline Total & 399 & 97274 & & & \\
\hline Transformation: & pres/abs & & & & \\
\hline \multicolumn{6}{|c|}{$\begin{array}{l}\text { Two-way PERMANOVA comparing assemblage composition between natural and } \\
\text { artificial habitats. }\end{array}$} \\
\hline Source & df & SS & MS & Pseudo-F & $\mathrm{P}($ perm $)$ \\
\hline Habitat & 1 & 24297 & 24297 & 6.3912 & 0.0006 \\
\hline Site(Habitat) & 18 & 68443 & 3802.4 & 16.724 & 0.0001 \\
\hline Residual & 380 & 86397 & 227.36 & & \\
\hline Total & 399 & 179000 & & & \\
\hline Transformation: & fourth root & & & & \\
\hline
\end{tabular}

(b) Semi-quantitative data

\begin{tabular}{|c|c|c|c|c|c|}
\hline \multicolumn{6}{|c|}{ One-way ANOVA comparing species richness between natural and artificial habitats } \\
\hline Source & df & SS & MS & Pseudo-F & $\mathrm{P}($ perm $)$ \\
\hline Habitat & 1 & 94.912 & 94.912 & 0.59709 & 0.4781 \\
\hline Residual & 19 & 3020.2 & 158.96 & & \\
\hline Total & 20 & 3115.1 & & & \\
\hline Transformation: & pre & & & & \\
\hline \multicolumn{6}{|c|}{$\begin{array}{l}\text { One-way PERMANOVA comparing assemblage composition between natural and } \\
\text { artificial habitats. }\end{array}$} \\
\hline Source & df & SS & MS & Pseudo-F & $\mathrm{P}($ perm $)$ \\
\hline Habitat & 1 & 4854.7 & 4854.7 & 9.041 & 0.0001 \\
\hline Residual & 19 & 10202 & 536.96 & & \\
\hline Total & 20 & 15057 & & & \\
\hline Transformation: & fou & & & & \\
\hline
\end{tabular}

within regions revealed significantly higher richness in Torbay compared to Looe $(p=0.0084)$, Southampton compared to Portsmouth $(p=0.0030)$ and Shoreham compared to Folkestone $(p=0.0045)$. Pairwise comparisons showed that assemblage composition between the West and Central $(p=0.0012)$ and the Central and East $(p=0.0012)$ regions differed significantly. Differences in assemblage composition were found between Falmouth and Looe $(p=0.0232)$, Falmouth and Plymouth $(p=0.0292)$, Falmouth and Torbay $(p=0.0244)$, Looe and Torbay $(p=0.0073)$, Poole and Southampton $(p=0.0090)$, Southampton and Portsmouth $(p=0.0002)$ and Shoreham and Folkestone $(p=0.0034)$. SIMPER analysis revealed that the erect bryozoan, Bugula neritina (Linnaeus, 1758) contributed the most to the dissimilarity between West and Central (15\%; greater in Central); while $W$. subatra contributed the most to dissimilarities between West and East (37.3\%; greater in West) and Central and East regions (22.1\%; greater in Central).

Analysis of semi-quantitative search-based data revealed a significant difference in NNS richness among regions, with the Central region supporting greater mean and total richness per harbour compared to West $(p=0.0472)$ and East regions $(p=0.0014$; Table $3 \mathrm{~b}$, Figs. 3, 4b). There were no significant differences, however, in mean richness among harbours within regions (Table 3b, Fig. 4a). Assemblage composition varied significantly among both harbours and regions (Table 3b, Fig. 5). Post-hoc pairwise tests comparing regions showed that the West and Central $(p=0.0144)$ and Central and East $(p=0.0326)$ assemblage compositions differed significantly. Comparisons of harbours within regions found that assemblage composition differed significantly between Falmouth and Plymouth $(p=0.0355)$, Poole and Portsmouth $(p=0.0131)$, Poole and Southampton 


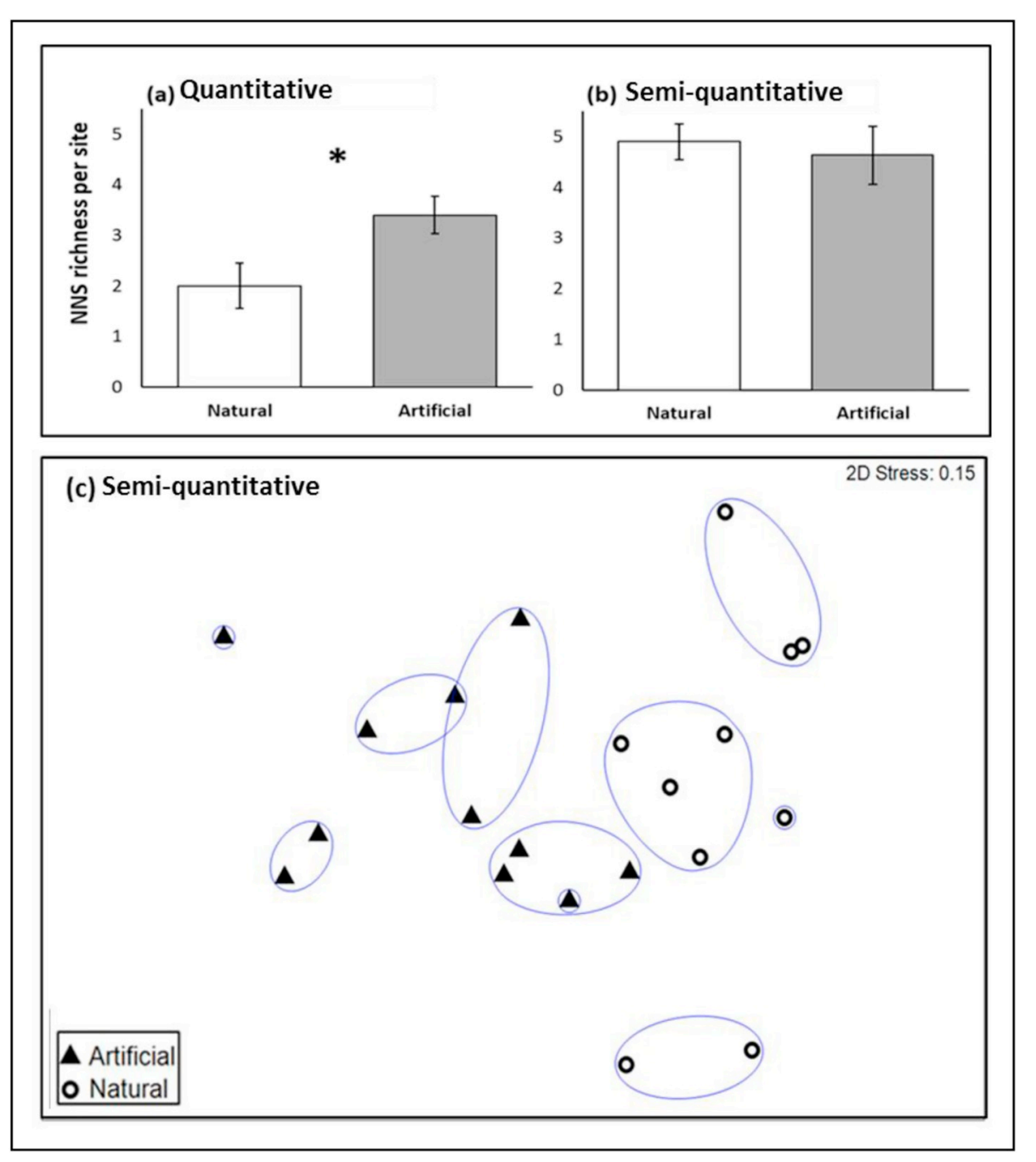

Fig. 2. Comparison of mean number of NNS per site in natural and artificial intertidal habitats using (a) quantitative quadrat and (b) semi-quantitative search-based sampling techniques. *NNS richness was significantly greater in artifical compared to natural habitats using quantitative techniques ( $p=0.0009$ ) but not using semi-quantitative methods (natural sites, $\mathrm{n}=10$; artificial sites, $\mathrm{n}=11$ ). Error bars show standard error. (c) Nonmetric multi-dimensional scaling plot (nMDS) showing significant difference in assemblage composition between natural and artificial sites using semi-quantitative search-based data. Assemblage composition between natural and artificial habitats differed significantly $(p=0.0001)$. The envelopes show a resemblance level of $75 \%$. $(p=0.0014)$ and Southampton and Portsmouth $(p=0.0013)$. SIMPER analysis revealed that $W$. subatra contributed the most to the dissimilarity between West and East regions (25.4\%; greater in West), while $C$. okamurae contributed the most to dissimilarities between West and Central (11.4\%; greater in West) and Central and East regions (1.6\%; greater in East).

\subsection{Numbers and types of vessels by harbour}

Portsmouth and Southampton supported the greatest average number of vessel arrivals per day at 86.4 and 83.1, respectively, while Folkestone supported the fewest (0.4; Fig. 4c). The Central region supported the greatest average number of vessels per day at 61.6 , while the West supported the fewest at 7.9 (Fig. 4d). International shipping (container liner services) occurs out of Southampton with 12 carriers, as well as Plymouth and Dover with one carrier each (Table 1). Seven of the 12 container liner carriers that visit Southampton operate globally, with destinations in North and South America, Asia, India, the Pacific Islands, Australia, Europe, the Middle East, Africa and the Caribbean (World Port Source, 2019). The carrier that operates out of Plymouth is also a global carrier (similar destinations as listed above), while the carrier out of Dover only operates out of northern Europe. International cruise liners operate out of Southampton with global destinations, while cruise liners out of Dover have European destinations only. Ferries to northern Europe (France and Spain) operate from Plymouth, Poole, Portsmouth and Dover, while military bases are located in Falmouth, Plymouth and Portsmouth (Table 1, Fig. 1).

\section{Discussion}

Twenty-six non-native sessile invertebrates and macroalgae were found during Rapid Assessment Surveys of artificial structures in harbours along the south coast of England. Comparisons of NNS between natural and artificial habitats found that assemblage compositions differed significantly, but differences in richness depended on the sampling technique employed. The Central region supported greater mean and total richness, as well as different assemblage compositions, compared to the West and East regions. These differences might be attributed to regional shipping patterns, as most harbours in this study with high NNS richness saw relatively large amounts of vessel traffic.

Our study provided mixed evidence to support the hypothesis that artificial sites would support greater NNS richness compared to natural sites, as results differed depending on sampling method employed. Analysis of quantitative stratified-random quadrat data found differences in richness between natural and artificial habitats, while analysis of semi-quantitative search-based data (obtained from timed searches including complex habitats) did not detect differences. Both sampling techniques, however, showed that NNS assemblages between natural and artificial habitats were indeed different. These results agreed to some extent with previous studies that found assemblages of NNS differed between natural and artificial subtidal habitats (Glasby et al., 2007; Tyrrell and Byers, 2007; Dafforn et al., 2012). Conversely, the result that richness did not differ between natural and artificial habitats from our study contrasts with work from these same studies listed above which showed that artificial supported more NNS than natural 
Table 3

PERMANOVA results for comparison of NNS richness and assemblage composition using (a) quantitative quadrat data and (b) semi-quantitative searchbased data in artificial habitats among harbours and regions. Significant $p$-values are in bold.

(a) Quantitative data

\begin{tabular}{llllll}
\hline $\begin{array}{l}\text { Three-way PERMANOVA comparing species richness among regions, harbours and } \\
\quad \text { sites. }\end{array}$ & df & SS & MS & Pseudo-F & P(perm) \\
Source & 2 & 60707 & 30354 & 7.0537 & $\mathbf{0 . 0 0 2 5}$ \\
Region & 7 & 118340 & 16905 & 3.9287 & $\mathbf{0 . 0 0 1 9}$ \\
$\begin{array}{l}\text { Harbour(Region) } \\
\text { Site(Harbour }\end{array}$ & 30 & 118340 & 4303.2 & 15.623 & $\mathbf{0 . 0 0 0 1}$ \\
$\quad$ (Region)) & & & & & \\
$\begin{array}{l}\text { Residual } \\
\text { Total }\end{array}$ & 760 & 118340 & 275.44 & & \\
Transformation: & 799 & 118340 & & & \\
\end{tabular}

Three-way PERMANOVA comparing assemblage composition among regions, harbours and sites.

$\begin{array}{llllll}\text { Source } & \mathrm{df} & \text { SS } & \text { MS } & \text { Pseudo-F } & \text { P(perm) } \\ \text { Region } & 2 & 75905 & 37953 & 4.5881 & \mathbf{0 . 0 0 4 0} \\ \text { Harbour(Region) } & 7 & 221400 & 31628 & 3.8236 & \mathbf{0 . 0 0 0 1} \\ \begin{array}{l}\text { Site(Harbour } \\ \quad \text { Region)) }\end{array} & 30 & 248160 & 8272 & 11.922 & \mathbf{0 . 0 0 0 1} \\ \begin{array}{l}\text { Residual } \\ \text { Total }\end{array} & 760 & 527330 & 693.85 & & \\ \text { Transformation: } & 799 & 1155800 & & & \\ & \text { fourth root } & & & & \end{array}$

(b) Semi-quantitative data

\begin{tabular}{|c|c|c|c|c|c|}
\hline Source & df & SS & MS & Pseudo-F & $\mathrm{P}($ perm $)$ \\
\hline Region & 2 & 4014 & 2007 & 7.0275 & 0.0012 \\
\hline Harbour(Region) & 8 & 2399.2 & 299.9 & 1.0501 & 0.4183 \\
\hline Residual & 33 & 9424.5 & 285.59 & & \\
\hline Total & 43 & 18170 & & & \\
\hline Transformation: & pre & & & & \\
\hline \multicolumn{6}{|c|}{$\begin{array}{l}\text { Two-way PERMANOVA comparing assemblage composition among regions and } \\
\text { harbours. }\end{array}$} \\
\hline Source & df & SS & MS & Pseudo-F & $\mathrm{P}($ perm $)$ \\
\hline Region & 2 & 12842 & 6420.9 & 7.586 & 0.0001 \\
\hline Harbour(Region) & 8 & 15168 & 1896 & 2.24 & 0.0028 \\
\hline Residual & 33 & 27931 & 846.41 & & \\
\hline Total & 43 & 65127 & & & \\
\hline Transformation: & fou & & & & \\
\hline
\end{tabular}

habitats. For example, Glasby et al. (2007) found that numbers of NNS were markedly greater on floating pontoons and pilings than on natural rocky reef. Furthermore, Tyrrell and Byers (2007) and Dafforn et al. (2012) experimentally showed that non-native fouling species outcompeted native species on artificial structures, but non-natives were not able to gain a foothold on natural substrate. Importantly, all of these studies were done in subtidal habitats (many on floating pontoons), which may explain the conflicting results. In the current study, semiquantitative search-based sampling techniques allowed complex microhabitats to be searched (e.g., rock pools, crevices and gaps between boulders). Natural substrate generally provides more topographic complexity compared to artificial structures (Moschella et al., 2005; Chapman and Underwood, 2011). Thus, it is not surprising that many more NNS were observed during the searches in natural than artificial habitats. For example, while $S$. muticum, C. pergrina, U. pinnatifida, A. armata and G. turuturu were found in previous studies of artificial habitats (Arenas et al., 2006; Firth et al., 2013; Bishop et al., 2015b), they were only found in rock pools during timed searches in natural habitats in our study. This indicates the importance of water-retaining features for the successful establishment of non-native species on typically diverse natural rocky shores. These features have previously been identified as being important for providing shade and water retention at low tide to alleviate desiccation for native species in intertidal habitats (Firth et al., 2013, Firth et al., 2016b). Conversely, in the subtidal zone, as desiccation is not a concern, topographic complexity may be needed for entirely different reasons, such as providing larvae and propagules refuge from predators or wave movement (Kovalenko et al., 2012; Strain et al., 2017). Different uses of topographic complexity by resident organisms between intertidal and subtidal habitats may be a reason for the differential results obtained between previous surveys and the current survey.

The frequency of arriving vessels, types and departure points of vessels arriving in harbours, as well as the subsequent secondary destinations to which species can be transported (Carlton, 1996b; Ruiz et al., 2000; Clarke Murray et al., 2011), may explain the high number and variety of NNS around Southampton and the Central region in general. The success of an introduced species is highly dependent on propagule pressure (Lockwood et al., 2005; Copp et al., 2010), and thus it is not surprising that most of the harbours supporting relatively high species richness were also harbours that supported a high frequency of arriving vessels. For example, Southampton was unique in our study in

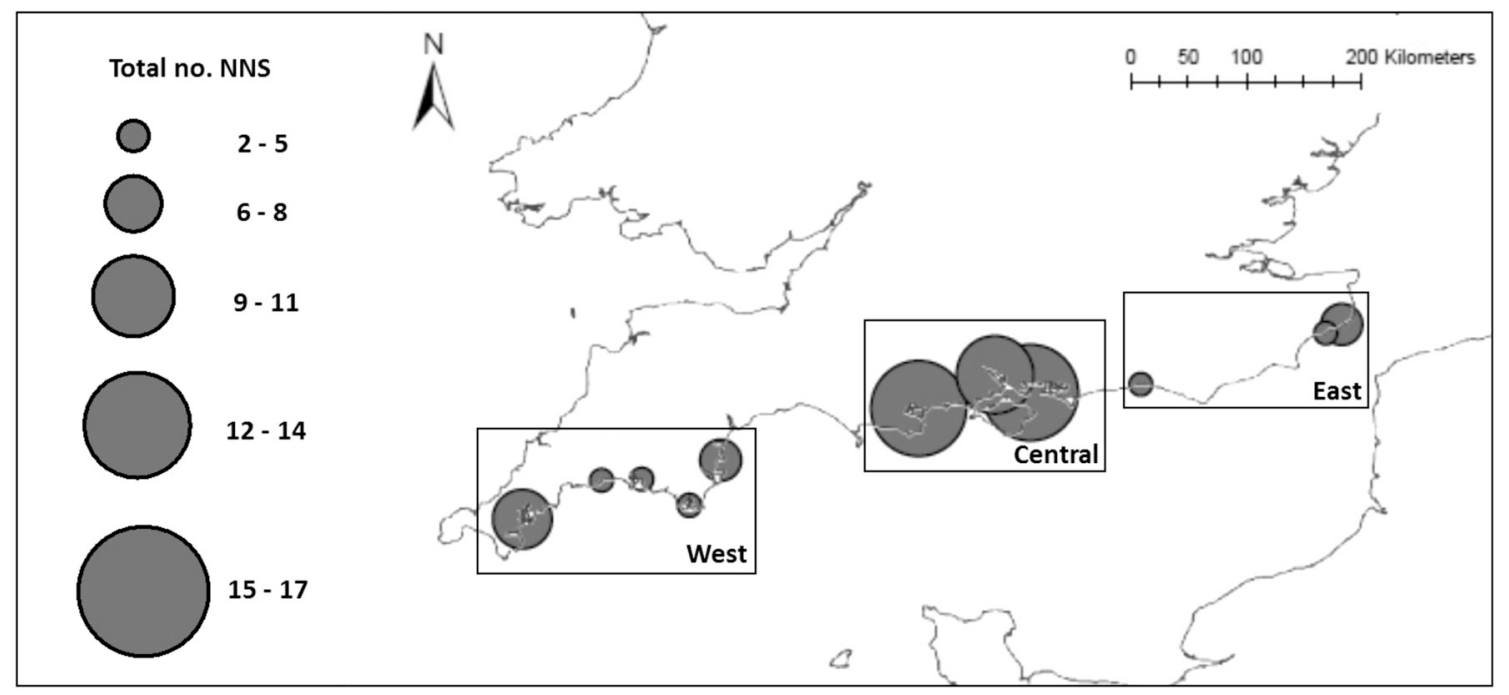

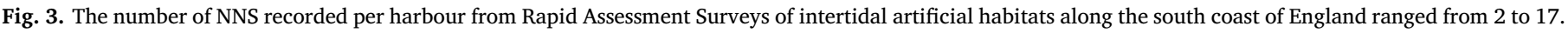

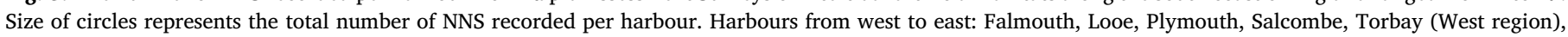

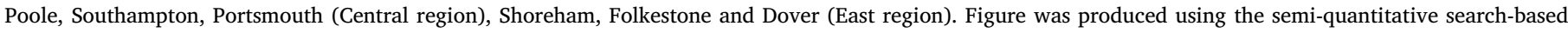
data. 

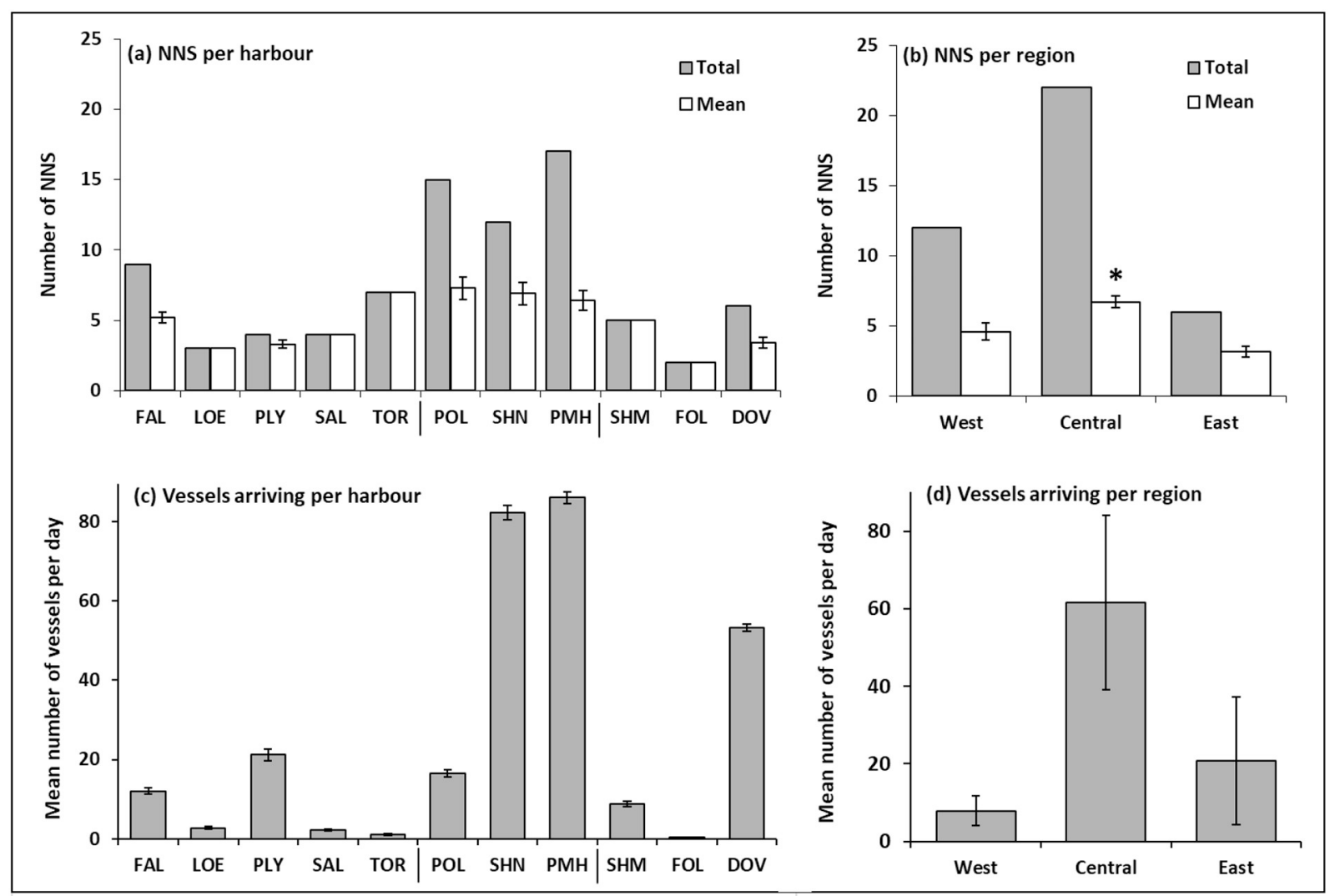

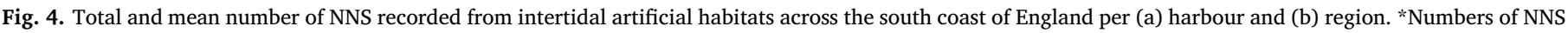

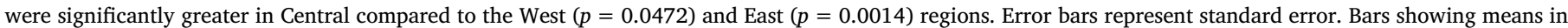

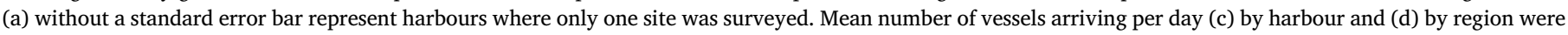

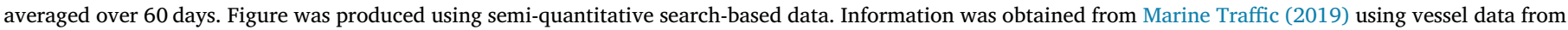
February and March 2019.

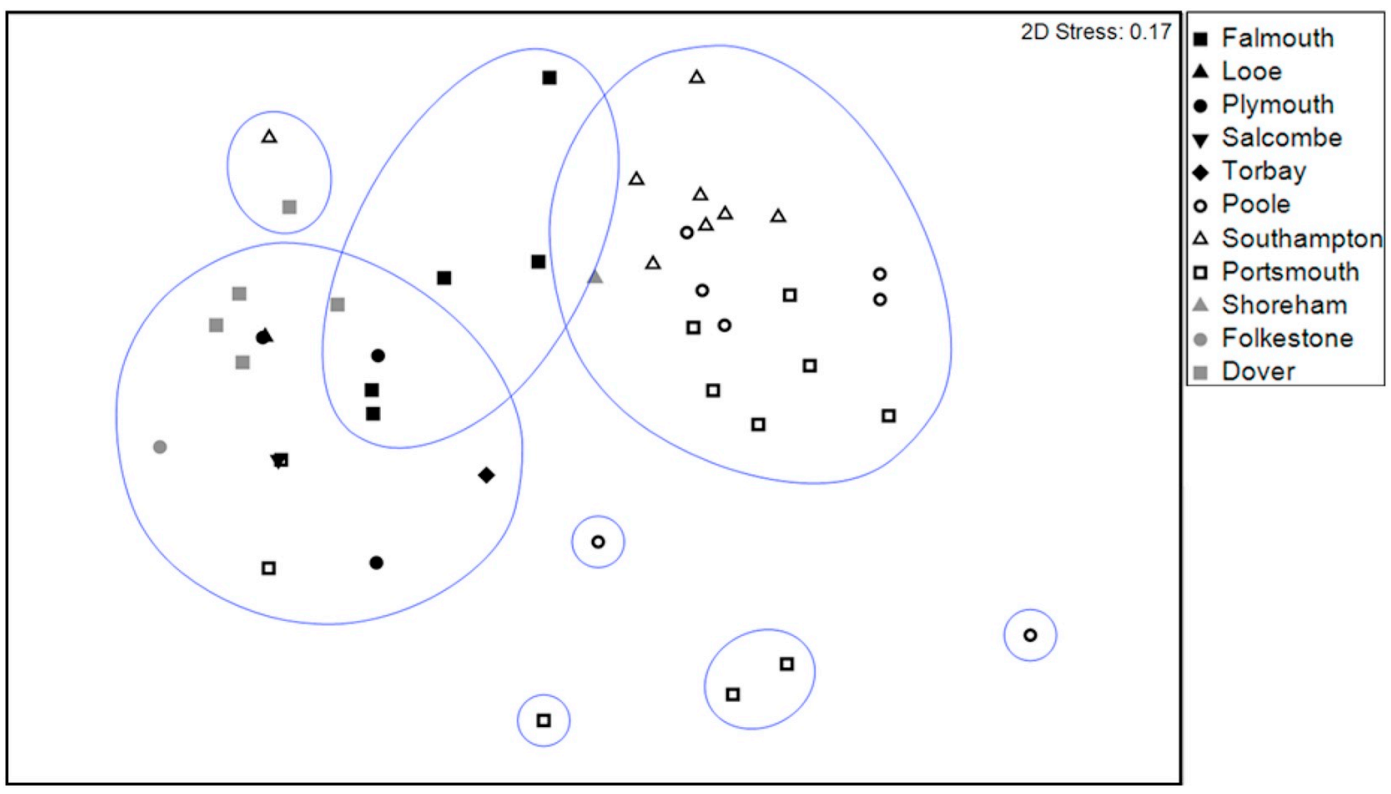

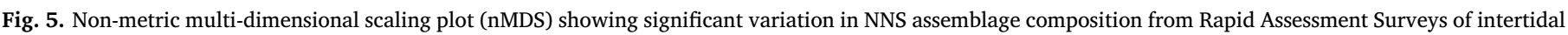

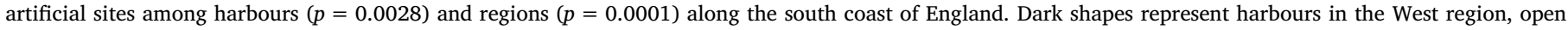

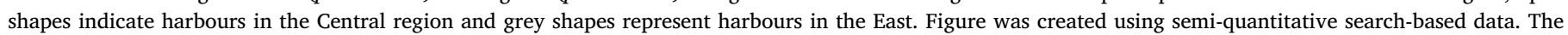
envelopes show a resemblance level of $60 \%$. 
being one of the largest cruise ship and container ports in the UK, and the busiest along the English south coast (Associated British Ports, 2019; Marine Traffic, 2019; World Port Source, 2019). As such, it sees significantly more international traffic than any other of the south coast ports. Global movement of NNS into the British Isles has been described by Eno et al. (1997) who proposed scenarios depicting likely invasion pathways. Many species were proposed to have been transferred directly to the British Isles from their places of origin, such as B. hamifera from Southeast Asia, A. modestus from Australia and C. fornicata from the eastern seaboard of the US. These routes of transfer explain high propagule pressure in the port of Southampton, where cargo tankers regularly arrive from international ports. However, Eno et al. (1997) suggested many other non-natives (i.e., A. armata, S. muticum, C. peregrina) were first transported from their origin to continental Europe, followed by a secondary transfer into the British Isles across the English Channel. Bishop et al. (2015a) provided evidence for this, as their Rapid Assessment Surveys showed a general pattern of northward movement of NNS from Brittany, France across the English Channel to South West England over time. This invasion pathway might explain the high numbers of NNS in Portsmouth (and to a lesser degree, Poole), where large passenger ferries arrive from northern European destinations. The current study can only suggest the above as invasion pathways, as identifying NNS from source ports was outside the scope of this study. Thus, future research can focus on providing evidence by groundtruthing these results or using molecular markers to show that the same NNS occurred in the departing international harbours as the receiving ports in southern England.

Although the relationship between NNS richness and number of vessels arriving per day was clear at the regional level (i.e., West, Central, East), at the harbour level, there were some harbours that did not follow this trend. Poole Harbour supported a relatively high number of NNS, yet the number of arriving vessels was relatively low compared to other harbours with high species richness (i.e., Portsmouth and Southampton). This suggests that factors other than propagule pressure from international shipping play a role in determining success of NNS. The geomorphology of Poole is quite different than the other harbours in this study, in that the harbour itself has a very narrow mouth, a double high tide daily and the smallest tidal range in the study area (1.8 m), as well as very poor flushing (Humphreys, 2005; May, 2005; World Port Source, 2019). Poole has been described as a lagoon-like harbour; it is a shallow and warm body of water (Humphreys, 2005; May, 2005). These conditions may be particularly favourable for NNS originating from warmer waters, such as D. vexillum (Zaiko et al., 2007; Lambert, 2009). Moreover, slow and incomplete flushing of the harbour means larvae of NNS are present in the water for long periods of time, potentially allowing increased settlement compared to harbours with faster flushing times. These conditions are also favourable to yachting, and so smaller leisure craft regularly travel among harbours within the Solent (Central region; SJH pers. obs.), potentially acting as secondary mobile vectors (Clarke Murray et al., 2011). On the other hand, Dover sees a relatively high number of vessels per day but supports relatively few numbers of NNS. Although the numbers of vessels are high in Dover, the origins and destinations are almost exclusively European (Marine Traffic, 2019; World Port Source, 2019). This effectively means lower propagule pressure from global invaders directly. Moreover, the geomorphology of Dover is different from the other harbours in this study, in that Dover is not a natural bay or inlet. Rather, the port was artificially created when the Dover Southern Breakwater was constructed at the beginning of the 20th century. It is therefore likely that the hydrodynamics - which can affect turbidity and scouring of structures (Govarets and Lauwaert, 2009; Dugan et al., 2011), and can dictate transport of larvae in currents and tides (McQuaid and Phillips, 2000) - differ markedly between Dover and naturally-formed ports.

Evidence from this study and others suggest that artificial structures probably play an important role in the initial establishment and then secondary transport of NNS away from their initial point of introduction (Eno et al., 1997; Neves et al., 2007; Mineur et al., 2012). By nature, docks and floating pontoons are constantly in close proximity to cargo tankers, passenger ferries and recreational vessels, and thus there is a high probability of species spreading from mobile vectors (vessels) to stationary structures (floating pontoons, docks; Neves et al., 2007). In a study examining the fouling communities of boat hulls and associated floating pontoons and concrete structures in an international Brazilian port, Neves et al. (2007) found that biotic communities on hulls were similar to those on the pontoons; while communities on concrete structures were a similar but smaller subset of the species found on hulls. This is because boat hulls and floating pontoons rise and fall with the tide, while concrete structures are fixed in place (similar to intertidal natural rocky shores). Hulls of recreational boats are regularly cleaned of fouling organisms (Neves et al., 2007); it is even becoming increasingly common for transoceanic vessels to undergo regular hull cleaning (Hopkins and Forrest, 2008; PML Applications Ltd, 2019). Thus, the biological communities they support are typically younger (i.e. at earlier successional stages) than those on floating pontoons and associated docks. As such, pontoons act as "reservoirs" of established NNS communities (Neves et al., 2007; Floerl et al., 2009; Foster et al., 2016), while concrete structures support fewer numbers of species, but of which have the ability to invade intertidal natural habitats (Neves et al., 2007; Epstein and Smale, 2018). In our study, harbours east of Torbay were dominated by sedimentary substrata, thus fouling organisms typical of natural rocky shores arriving from distant hard substrata have only been able to establish and survive by colonising artificial structures in these otherwise uninhabitable areas. In this way, artificial structures may affect ecological connectivity by providing "stepping stones" for the movement of species across seascapes (Sammarco et al., 2004; Airoldi et al., 2015; Bishop et al., 2017). Moreover, smaller harbours (e.g., Folkestone) with many fewer artificial structures compared to larger harbours (e.g., Portsmouth) provided less hard substrata for NNS spread from a mobile vector to a stationary structure. These smaller harbours also supported less diverse NNS communities due to lower diversity of artificial structures (e.g., Folkestone Harbour is largely composed of rock and concrete seawalls and lacks floating pontoons). As such, these smaller harbours are less likely to act as NNS reservoirs.

The limitations of sampling natural and artificial sites equally are extremely challenging to overcome; yet a combined sampling approach (quantitative stratified-random quadrats and semi-quantitative timed searches), like those employed in this study, can address some of the problems associated with sampling in these habitats. By nature, complex microhabitats on gently sloping natural rocky shores (e.g., rock pools, gaps between boulders) are generally easier (and safer) to sample compared to those on artificial structures. This was acknowledged in the methods of the current study by slightly extending the timed search on structures that were difficult to sample due to safety and logistical reasons. For example, boulder groynes and riprap revetment provide internal compartments created by the stacking of boulders to maximise coastal protection. The interior of these structures provide functional niches that are absent on the exterior that protect organisms from desiccation, wave exposure and sand scour; thus species diversity tends to be greater within the internal compartments, which are difficult to access/observe (Sherrard et al., 2016; Liversage and Chapman, 2018). Traditional quadrat sampling avoids gaps between boulders and other complex microhabitats, consequently missing vital species diversity information. Therefore, numbers and abundances of NNS recorded from the exterior of these structures probably do not accurately represent the true NNS diversity of the entire structure. On the other hand, limited areal extent provided by other artificial structures, such as seawalls, means that the likelihood of these structures to be fully sampled ("censused"; Chapman et al., 2018) using quadrat sampling techniques is much greater than on a large natural rocky shore or more complex artificial structures, where many diverse habitats are likely to be missed (Chapman et al., 2018). In the current study, quadrat sampling was able 
to cover most of the available area on seawalls but missed areas in larger natural sites (e.g., rock pools). If quantitative quadrat sampling alone had been used (which is a typical method in biodiversity surveys), our study would have concluded that intertidal artificial habitats support greater (mean) numbers of NNS (per unit area) than natural habitats. By employing a timed search, this study came to a very different conclusion - that of which challenges the commonly accepted concept that artificial structures support greater NNS richness compared to natural rocky shores. Most NNS surveys along the south coast of England have focused on surveying marina pontoons in subtidal habitats (Arenas et al., 2006; Ashton et al., 2006; Bishop et al., 2015a, 2015b; Foster et al., 2016), as these are known "hot spots" for introduction. Our study demonstrated that areas not labelled as "hot spots", such as natural rocky shores, should not be ignored. A recent report cautioned that natural rocky shores might facilitate "spillover" of NNS from populations in marinas to natural habitats, facilitating the spread out from the initial sites of introduction (Epstein and Smale, 2018). Although not explicitly tested for, our study showed that intertidal natural sites do indeed support many NNS and may actually contribute to their spread between major transport hubs and surrounding bays and harbours.

Results from this study could be strengthened by formal tests on the effects of local environmental and physical conditions on success of NNS establishment. Physical factors, such as hydrodynamics (Horvath and Crane, 2010; Zardi et al., 2006) and pollution load (Dafforn et al., 2011; McKenzie et al., 2011) are important in influencing NNS colonisation and competition with native biota. For example, previous studies have shown that industrial and urban runoff adversely affects native composition and ecological functioning of marine communities (Johnston and Roberts, 2009; Burton and Johnston, 2010), and that species response (recolonisation) can vary depending on exposure to particular contaminants (Trannum et al., 2004). Additionally, NNS have been shown to tolerate contaminants and pollution while abundances of native species decline under the same conditions (Crooks et al., 2011; Dafforn et al., 2011; McKenzie et al., 2011). Thus, a decline in native biotic communities can easily give NNS a competitive advantage where conditions are unfavourable for native species (Johnston et al., 2017).

The loss of natural habitat caused by coastal development and ocean sprawl is leading to the need to explore alternative options to traditional hard built structures for coastal protection (Dafforn et al., 2015a; Firth et al., 2016a). There is therefore an increasing impetus to ecologically enhance hard structures to fulfill secondary management goals, such as increase biodiversity, enhance ecosystem services or reduce abundance of NNS (i.e., "ecological engineering”; Dafforn, 2017; Evans et al., 2017; Strain et al., 2019a, 2019b). Results from our surveys clearly demonstrate that ecological engineering designs must consider the potential for colonisation by NNS (Sella and Perkol-Finkel, 2015; Dafforn, 2017; Strain et al., 2017). Traditionally, ecological engineering interventions that have included rock pools retrofitted onto seawalls (Chapman and Underwood, 2011; Browne and Chapman, 2014) or drilling pits into seawalls or breakwaters (Firth et al., 2014; Evans et al., 2016), have been advocated as a means of enhancing species diversity through water retention. Our survey showed that these interventions may increase the risk of colonisation by NNS, such as $S$. muticum and $U$. pinnatifida, which were regularly found in rock pools in natural sites. Information from biodiversity studies and Rapid Assessment Surveys should thus serve as a benchmark against which to measure change to biotic communities over time, and is an essential first step in informing management decisions concerning design details for ecological engineering of artificial structures in coastal intertidal habitats (Dafforn et al., 2015b; Mayer-Pinto et al., 2017).

Ocean sprawl is accelerating the rate of NNS introduction and spread, contributing to biotic homogenisation and the growing biodiversity crisis. Understanding the ecological role of artificial structures in the marine and coastal environments is critical for preserving native biodiversity and building resilience to establishment of NNS. Our results suggest that global shipping and artificial structures may play an important role in the introduction and spread of NNS. Other factors such as local environmental conditions and geomorphology of harbours undoubtedly contribute to NNS success, but disentangling these factors is difficult. Therefore, all potential mechanisms of NNS introduction, establishment and spread need investigation so that ecologists might develop the predictive capability to identify areas at high risk of invasion, which can aid in effective forecasting for potential invaders.

Supplementary data to this article can be found online at https:// doi.org/10.1016/j.marpolbul.2020.111082.

\section{CRediT authorship contribution statement}

Kathryn A. O'Shaughnessy: Conceptualization, Investigation, Formal analysis, Visualization, Writing - original draft, Writing - review \& editing, Project administration. Stephen J. Hawkins: Conceptualization, Methodology, Writing - review \& editing, Funding acquisition. Anna L.E. Yunnie: Validation, Resources, Writing - review \& editing. Mick E. Hanley: Conceptualization, Methodology, Writing review \& editing. Paul Lunt: Conceptualization, Methodology, Writing - review \& editing. Richard C. Thompson: Conceptualization, Methodology, Writing - review \& editing. Louise B. Firth: Conceptualization, Methodology, Resources, Validation, Visualization, Writing - review \& editing, Supervision, Project administration.

\section{Acknowledgements}

The authors are grateful to J. D. D. Bishop, C. A. Wood and F. Bunker for help with species identification.

\section{Funding}

This work was supported by the University of Plymouth (KAO). Write-up was facilitated by funding from SJH (KAO).

\section{Declaration of competing interest}

The authors declare that they have no known competing financial interests or personal relationships that could have appeared to influence the work reported in this paper.

\section{References}

Airoldi, L., Bulleri, F., 2011. Anthropogenic disturbance can determine the magnitude of opportunistic species responses on marine urban infrastructures. PLoS One 6, e22985. https://doi.org/10.1371/journal.pone.0022985.

Airoldi, L., Turon, X., Perkol-Finkel, S., Rius, M., 2015. Corridors for aliens but not for natives: effects of marine urban sprawl at a regional scale. Divers. Distrib. 21, 755-768. https://doi.org/10.1111/ddi.12301.

Anderson, M.J., 2001. A new method for non-parametric multivariate analysis of variance. Austral Ecol. 26, 32-46. https://doi.org/10.1111/j.1442-9993.2001.01070. pp.x.

Anderson, M., Gorley, R.N., Clarke, R.K., 2008. Permanova + for Primer: Guide to Software and Statistical Methods. Primer-E Limited.

Apte, S., Holland, B.S., Godwin, L.S., Gardner, J.P., 2000. Jumping ship: a stepping stone event mediating transfer of a non-indigenous species via a potentially unsuitable environment. Biol. Invasions 2, 75-79. https://doi.org/10.1023/A:1010024818644.

Arenas, F., Bishop, J.D.D., Carlton, J.T., Dyrynda, P.J., Farnham, W.F., Gonzalez, D.J. Jacobs, M.W., Lambert, C., Lambert, G., Nielsen, S.E., Pederson, J.A., Porter, J.S., Ward, S., Wood, C.A., 2006. Alien species and other notable records from a rapid assessment survey of marinas on the south coast of England. J. Mar. Biol. Assoc. UK 86, 1329-1337. https://doi.org/10.1017/S0025315406014354.

Ashton, G., Boos, K., Shucksmith, R., Cook, E., 2006. Rapid assessment of the distribution of marine non-native species in marinas in Scotland. Aquat. Invasions 1, 209-213.

Bax, N., Williamson, A., Aguero, M., Gonzalez, E., Geeves, W., 2003. Marine invasive alien species: a threat to global biodiversity. Mar. Policy 27, 313-323. https://doi. org/10.1016/S0308-597X(03)00041-1.

Bishop, J.D., Wood, C.A., Lévêque, L., Yunnie, A.L., Viard, F., 2015a. Repeated rapid assessment surveys reveal contrasting trends in occupancy of marinas by non-indigenous species on opposite sides of the western English Channel. Mar. Pollut. Bull. 95, 699-706. https://doi.org/10.1016/j.marpolbul.2014.11.043.

Bishop, J.D.D., Wood, C.A., Yunnie, A.L.E., Griffiths, C.A., 2015b. Unheralded arrivals: 
non-native sessile invertebrates in marinas on the English coast. Aquat. Invasions 10, 249-264. https://doi.org/10.3391/ai.2015.10.3.01.

Bishop, M.J., Mayer-Pinto, M., Airoldi, L., Firth, L.B., Morris, R.L., Loke, L.H., Hawkins, S.J., Naylor, L.A., Coleman, R.A., Chee, S.Y., Dafforn, K.A., 2017. Effects of ocean sprawl on ecological connectivity: impacts and solutions. J. Exp. Mar. Biol. Ecol. 492, 7-30. https://doi.org/10.1016/j.jembe.2017.01.021.

Browne, M.A., Chapman, M.G., 2014. Mitigating against the loss of species by adding artificial intertidal pools to existing seawalls. Mar. Ecol. Prog. Ser. 497, 119-129. https://doi.org/10.3354/meps10596.

Bulleri, F., Chapman, M., Underwood, A., 2005. Intertidal assemblages on seawalls and vertical rocky shores in Sydney Harbour, Australia. Austral Ecol. 30, 655-667. https://doi.org/10.1111/j.1442-9993.2005.01507.x.

Burrows, M., Hawkins, S., Southward, A., 1992. A comparison of reproduction in cooccurring chthamalid barnacles, Chthamalus stellatus (Poli) and Chthamalus montagui Southward. J. Exp. Mar. Biol. Ecol. 160, 229-249. https://doi.org/10.1016/00220981(92)90240-B.

Burton, G.A., Johnston, E.L., 2010. Assessing contaminated sediments in the context of multiple stressors. Environ. Toxicol. Chem. 29, 2625-2643. https://doi.org/10.1007/ s10530-010-9799-3.

Byers, J.E., 2002. Impact of non-indigenous species on natives enhanced by anthropogenic alteration of selection regimes. Oikos 97, 449-458. https://doi.org/10.1034/ j.1600-0706.2002.970316.x.

Carlton, J.T., 1996a. Biological invasions and cryptogenic species. Ecology 77, $1653-1655$.

Carlton, J.T., 1996b. Pattern, process, and prediction in marine invasion ecology. Biol. Conserv. 78, 97-106. https://doi.org/10.1016/0006-3207(96)00020-1.

Carlton, J.T., Geller, J.B., 1993. Ecological roulette: the global transport of nonindigenous marine organisms. Science 261, 78-82. https://doi.org/10.1126/science.261. 5117.78.

Carman, M.R., Grunden, D.W., 2010. First occurrence of the invasive tunicate Didemnum vexillum in eelgrass habitat. Aquat. Invasions 5, 23-29. https://doi.org/10.3391/ai. 2010.5.1.4.

Chapman, M.G., Underwood, A.J., 2011. Evaluation of ecological engineering of "armoured" shorelines to improve their value as habitat. J. Exp. Mar. Biol. Ecol. 400, 302-313. https://doi.org/10.1016/j.jembe.2011.02.025.

Chapman, M.G., Underwood, A.J., Browne, M.A., 2018. An assessment of the current usage of ecological engineering and reconciliation ecology in managing alterations to habitats in urban estuaries. Ecol. Eng. 120, 560-573.

Clarke Murray, C., Pakhomov, E.A., Therriault, T.W., 2011. Recreational boating: a large unregulated vector transporting marine invasive species. Divers. Distrib. 17, 1161-1172. https://doi.org/10.1111/j.1472-4642.2011.00798.x.

Copp, G., Vilizzi, L., Gozlan, R., 2010. The demography of introduction pathways, propagule pressure and occurrences of non-native freshwater fish in England. Aquat. Conserv. Mar. Freshwat. Ecosyst. 20, 595-601. https://doi.org/10.1002/aqc.1129.

Crooks, J.A., Chang, A.L., Ruiz, G.M., 2011. Aquatic pollution increases the relative success of invasive species. Biol. Invasions 13, 165-176. https://doi.org/10.1007/ s10530-010-9799-3.

Dafforn, K.A., 2017. Eco-engineering and management strategies for marine infrastructure to reduce establishment and dispersal of non-indigenous species. Manag. Biol. Invasions 8, 153-161. https://doi.org/10.3391/mbi.2017.8.2.03.

Dafforn, K.A., Johnston, E.L., Glasby, T.M., 2009. Shallow moving structures promote marine invader dominance. Biofouling 25, 277-287. https://doi.org/10.1080/ 08927010802710618.

Dafforn, K.A., Lewis, J.A., Johnston, E.L., 2011. Antifouling strategies: history and regulation, ecological impacts and mitigation. Mar. Pollut. Bull. 62, 453-465. https:// doi.org/10.1016/j.marpolbul.2011.01.012.

Dafforn, K.A., Glasby, T.M., Johnston, E.L., 2012. Comparing the invasibility of experimental "reefs" with field observations of natural reefs and artificial structures. PLoS One 7, e38124. https://doi.org/10.1371/journal.pone.0038124.

Dafforn, K.A., Glasby, T.M., Airoldi, L., Rivero, N.K., Mayer-Pinto, M., Johnston, E.L., 2015a. Marine urbanization: an ecological framework for designing multifunctional artificial structures. Front. Ecol. Environ. 13, 82-90. https://doi.org/10.1890/ 140050.

Dafforn, K.A., Mayer-Pinto, M., Morris, R.L., Waltham, N.J., 2015b. Application of management tools to integrate ecological principles with the design of marine infrastructure. J. Environ. Manag. 158, 61-73. https://doi.org/10.1016/j.jenvman. 2015.05.001.

Dineen, J.F., Clark, P.F., Hines, A.H., Reed, S.A., Walton, H.P., 2001. Life history, larval description, and natural history of Charybdis hellerii (Decapoda, Brachyura, Portunidae), an invasive crab in the western Atlantic. J. Crustac. Biol. 21, 774-805. https://doi.org/10.1163/20021975-99990173.

Drake, J.M., Lodge, D.M., 2007. Hull fouling is a risk factor for intercontinental species exchange in aquatic ecosystems. Aquat. Invasions 2, 121-131. https://doi.org/10. 3391/ai.2007.2.2.7.

Duarte, C.M., Pitt, K.A., Lucas, C.H., Purcell, J.E., Uye, S., Robinson, K., Brotz, L., Decker, M.B., Sutherland, K.R., Malej, A., Madin, L., Mianzan, H., Gili, J.-M., Fuentes, V., Atienza, D., Pagés, F., Breitburg, D., Malek, J., Graham, W.M., Condon, R.H., 2012. Is global ocean sprawl a cause of jellyfish blooms? Front. Ecol. Environ. 11, 91-97. https://doi.org/10.1890/110246.

Dugan, J., Airoldi, L., Chapman, M., Walker, S., Schlacher, T., 2011. Estuarine and coastal structures: environmental effects, a focus on shore and nearshore structures. Treatise on Estuarine and Coastal Science 8, 17-41. https://doi.org/10.1016/B978-0-12374711-2.00802-0.

Eno, N.C., Sanderson, W.G., Conservation, J., 1997. Non-native Marine Species in British Waters: A Review and Directory. JNCC, Petersborough.

Epstein, G., Smale, D.A., 2018. Environmental and ecological factors influencing the spillover of the non-native kelp, Undaria pinnatifida, from marinas into natural rocky reef communities. Biol. Invasions 20, 1049-1072. https://doi.org/10.1007/s1053.

Evans, A.J., Firth, L.B., Hawkins, S.J., Morris, E.S., Goudge, H., Moore, P.J., 2016. Drillcored rock pools: an effective method of ecological enhancement on artificial structures. Mar. Freshw. Res. 67, 123-130. https://doi.org/10.1071/MF14244.

Evans, A.J., Garrod, B., Firth, L.B., Hawkins, S.J., Morris-Webb, E.S., Goudge, H., Moore, P.J., 2017. Stakeholder priorities for multi-functional coastal defence developments and steps to effective implementation. Mar. Policy 75, 143-155. https://doi.org/10. 1016/j.marpol.2016.10.006.

Firth, L.B., Thompson, R.C., White, F.J., Schofield, M., Skov, M.W., Hoggart, S.P., Jackson, J., Knights, A.M., Hawkins, S.J., 2013. The importance of water-retaining features for biodiversity on artificial intertidal coastal defence structures. Divers. Distrib. 19, 1275-1283. https://doi.org/10.1111/ddi.12079.

Firth, L.B., Thompson, R.C., Bohn, K., Abbiati, M., Airoldi, L., Bouma, T.J., Bozzeda, F., Ceccherelli, V.U., Colangelo, M.A., Evans, A., Ferrario, F., Hanley, M.E., Hinz, H., Hoggart, S.P.G., Jackson, J.E., Moore, P.J., Morgan, E.H., Perkol-Finkel, S., Skov, M.W., Strain, E.M., Belzen, J.V., Hawkins, S.J., 2014. Between a rock and a hard place: environmental and engineering considerations when designing coastal defence structures. Coast. Eng. 87, 122-135. https://doi.org/10.1016/j.coastaleng.2013.10. 015.

Firth, L.B., Knights, A.M., Bridger, D., Evans, A.J., Mieszkowska, N., Hawkins, S.J., Moore, P.J., O'Connor, N.E., Sheehan, E.V., Thompson, R.C., 2016a. Ocean sprawl: challenges and opportunities for biodiversity management in a changing world. Oceanogr. Mar. Biol. Annu. Rev. 54, 189-262. https://doi.org/10.1201/ 9781315368597.

Firth, L.B., White, F.J., Schofield, M., Hanley, M.E., Burrows, M.T., Thompson, R.C., Skov, M.W., Evans, A.J., Moore, P.J., Hawkins, S.J., 2016b. Facing the future: the importance of substratum features for ecological engineering of artificial habitats in the rocky intertidal. Mar. Freshw. Res. 67, 131-143. https://doi.org/10.1071/MF14163.

Firth, L.B., Duff, L., Gribben, P.E., Knights, A.M., 2020. Facilitative Interactions Among Marine Invaders: Are Natural Habitats More at Risk Than Artificial Habitats? Ambio (review).

Floerl, O., Inglis, G., Dey, K., Smith, A., 2009. The importance of transport hubs in stepping-stone invasions. J. Appl. Ecol. 46, 37-45. https://doi.org/10.1111/j.13652664.2008.01540.x.

Foster, V., Giesler, R.J., Wilson, A.M.W., Nall, C.R., Cook, E.J., 2016. Identifying the physical features of marina infrastructure associated with the presence of non-native species in the UK. Mar. Biol. 163 (173). https://doi.org/10.1007/s00227-0162941-8.

Glasby, T.M., Connell, S.D., Holloway, M.G., Hewitt, C.L., 2007. Nonindigenous biota on artificial structures: could habitat creation facilitate biological invasions? Mar. Biol. 151, 887-895. https://doi.org/10.1007/s00227-006-0552-5.

Gollasch, S., 2002. The importance of ship hull fouling as a vector of species introductions into the North Sea. Biofouling 18, 105-121. https://doi.org/10.1080/ 08927010290011361.

Gollasch, S., 2008. Is Ballast Water a Major Dispersal Mechanism for Marine Organisms? Biological Invasions. Springer, pp. 49-57.

Govarets, A., Lauwaert, B., 2009. Assessment of the Impact of Coastal Defence Structures. Biodiversity Series: OSPAR Commission.

Griggs, G.B., 2005. The impacts of coastal armoring. Shore and Beach 73, 13-22.

Hitchcock, J.N., Mitrovic, S.M., 2019. Microplastic pollution in estuaries across a gradient of human impact. Environ. Pollut. 247, 457-466.

Hopkins, G.A., Forrest, B.M., 2008. Management options for vessel hull fouling: an overview of risks posed by in-water cleaning. ICES J. Mar. Sci. 65, 811-815. https:// doi.org/10.1093/icesjms/fsn026.

Horvath, T.G., Crane, L., 2010. Hydrodynamic forces affect larval zebra mussel (Dreissena polymorpha) mortality in a laboratory setting. Aquat. Invasions 5 (4), 379-385. https://doi.org/10.3391/ai.2010.5.4.07.

Humphreys, J., 2005. 3. Salinity and tides in Poole Harbour: estuary or lagoon? In: Proceedings in Marine Science. Elsevier, pp. 35-47.

Johnston, E.L., Roberts, D.A., 2009. Contaminants reduce the richness and evenness of marine communities: a review and meta-analysis. Environ. Pollut. 157, 17451752. https://doi.org/10.1016/j.envpol.2009.02.017.

Johnston, E.J., Dafforn, K.A., Clark, G.F., Rius, M., Floerl, O., 2017. How anthropogenic activities affect the establishment and spread of non-indigenous species post-arrival. Oceanogr. Mar. Biol. Annu. Rev. 55, 389-420.

Keller, R.P., Drake, J.M., Drew, M.B., Lodge, D.M., 2011. Linking environmental conditions and ship movements to estimate invasive species transport across the global shipping network. Divers. Distrib. 17, 93-102. https://doi.org/10.1111/j.1472-4642. 2010.00696.x.

Kinzie, R., 1984. Aloha also means goodbye: a cryptogenic stomatopod in Hawaii. Pac. Sci. 38, 298-311.

Kovalenko, K.E., Thomaz, S.M., Warfe, D.M., 2012. Habitat complexity: approaches and future directions. Hydrobiologia 685, 1-17. https://doi.org/10.1007/s10750-0110974-z.

Lambert, G., 2009. Adventures of a sea squirt sleuth: unraveling the identity of Didemnum vexillum, a global ascidian invader. Aquat. Invasions 4 (1), 5-28.

Liversage, K., Chapman, M., 2018. Coastal ecological engineering and habitat restoration: incorporating biologically diverse boulder habitat. Mar. Ecol. Prog. Ser. 593, 173-185. https://doi.org/10.3354/meps12541.

Lockwood, J.L., Cassey, P., Blackburn, T., 2005. The role of propagule pressure in explaining species invasions. Trends Ecol. Evol. 20, 223-228. https://doi.org/10.1016/ j.tree.2005.02.004.

Manchester, S.J., Bullock, J.M., 2000. The impacts of non-native species on UK biodiversity and the effectiveness of control. J. Appl. Ecol. 37, 845-864. https://doi.org/ 10.1046/j.1365-2664.2000.00538.x. 
Marine Traffic, 2019. Available. https://www.marinetraffic.com, Accessed date: 16 January 2019.

May, V., 2005. 2. Geomorphology of Poole Harbour. In: Proceedings in Marine Science. Elsevier, pp. 25-34.

Mayer-Pinto, M., Johnston, E.L., Bugnot, A.B., Glasby, T.M., Airoldi, L., Mitchell, A., Dafforn, K.A., 2017. Building 'blue': an eco-engineering framework for foreshore developments. J. Environ. Manag. 189, 109-114. https://doi.org/10.1016/j. jenvman.2016.12.039.

McKenzie, L.A., Brooks, R., Johnston, E.L., 2011. Heritable pollution tolerance in a marine invader. Environ. Res. 111, 926-932. https://doi.org/10.1016/j.envres.2010. 12.007.

McKinney, M.L., 2006. Urbanization as a major cause of biotic homogenization. Biol. Conserv. 127, 247-260. https://doi.org/10.1016/j.biocon.2005.09.005.

McKinney, M.L., Lockwood, J.L., 1999. Biotic homogenization: a few winners replacing many losers in the next mass extinction. Trends Ecol. Evol. 14, 450-453. https://doi. org/10.1016/S0169-5347(99)01679-1.

McQuaid, C.D., Phillips, T., 2000. Limited wind-driven dispersal of intertidal mussel larvae: in situ evidence from the plankton and the spread of the invasive species Mytilus galloprovincialis in South Africa. Mar. Ecol. Prog. Ser. 201, 211-220. https:// doi.org/10.3354/meps201211.

Mineur, F., Cook, E.J., Minchin, D., Bohn, K., Macleod, A., Maggs, C.A., 2012. Changing coasts: marine aliens and artificial structures. Oceanogr. Mar. Biol. 50, 189-234. https://doi.org/10.1201/b12157-5.

Mitsch, W.J., Jørgensen, S.E., 2003. Ecological engineering: a field whose time has come. Ecol. Eng. 20, 363-377. https://doi.org/10.1016/j.ecoleng.2003.05.001.

Molnar, J.L., Gamboa, R.L., Revenga, C., Spalding, M.D., 2008. Assessing the global threat of invasive species to marine biodiversity. Front. Ecol. Environ. 6, 485-492. https:// doi.org/10.1890/070064.

Moschella, P.S., Abbiati, M., Åberg, P., Airoldi, L., Anderson, J.M., Bacchiocchi, F., Bulleri, F., Dinesen, G.E., Frost, M., Gacia, E., 2005. Low-crested coastal defence structures as artificial habitats for marine life: using ecological criteria in design. Coast. Eng. 52, 1053-1071. https://doi.org/10.1016/j.coastaleng.2005.09.014.

Muxagata, E., Williams, J.A., Sheader, M., 2004. Composition and temporal distribution of cirripede larvae in Southampton Water, England, with particular reference to the secondary production of Elminius modestus. ICES J. Mar. Sci. 61, 585-595. https:// doi.org/10.1016/j.icesjms.2004.03.015.

Neves, C.S., Rocha, R.M., Pitombo, F.B., Roper, J.J., 2007. Use of artificial substrata by introduced and cryptogenic marine species in Paranaguá Bay, southern Brazil. Biofouling 23, 319-330. https://doi.org/10.1080/08927010701399174.

Odum, H.T., Odum, B., 2003. Concepts and methods of ecological engineering. Ecol. Eng. 20, 339-361. https://doi.org/10.1016/j.ecoleng.2003.08.008.

Pederson, J., Bullock, R., Carlton, J., Dijkstra, J., Dobroski, N., Dyrynda, P., Fisher, R., Harris, L., Hobbs, N., Lambert, G., 2005. Marine Invaders in the Northeast: Rapid Assessment Survey of Non-native and Native Marine Species of Floating Dock Communities, August 2003. Massachusetts Institute of Technology, Sea Grant College Program.

PML Applications Ltd, 2019. Available. https://pml-applications.co.uk/, Accessed date: 2 May 2019.

Ports, Associated British, 2019. Available. http://www.southamptonvts.co.uk/, Accessed date: 8 February 2019.

Ruiz, G.M., Carlton, J.T., Grosholz, E.D., Hines, A.H., 1997. Global invasions of marine and estuarine habitats by non-indigenous species: mechanisms, extent, and consequences. Am. Zool. 37, 621-632. https://doi.org/10.1093/icb/37.6.621.

Ruiz, G.M., Fofonoff, P.W., Carlton, J.T., Wonham, M.J., Hines, A.H., 2000. Invasion of coastal marine communities in North America: apparent patterns, processes, and biases. Annu. Rev. Ecol. Syst. 31, 481-531. https://doi.org/10.1146/annurev. ecolsys.31.1.481.

Sammarco, P.W., 2015. New Invasive Marine Species Colonizing Energy Platforms in the Northern Gulf of Mexico: Verification, and Examination of Spread. vol. 5. US Dept. of the Interior, Bureau of Ocean Energy Management, Gulf of Mexico OCS Region, New Orleans, LA. OCS Study BOEM, pp. 72.

Sammarco, P.W., Atchison, A.D., Boland, G.S., 2004. Expansion of coral communities within the Northern Gulf of Mexico via offshore oil and gas platforms. Mar. Ecol. Prog. Ser. 280, 129-143. https://doi.org/10.3354/meps280129.

Schneider, C.A., Rasband, W.S., Eliceiri, K.W., 2012. NIH Image to ImageJ: 25 years of image analysis. Nat. Methods 9, 671. https://doi.org/10.1038/nmeth.2089.

Seebens, H., Gastner, M., Blasius, B., Courchamp, F., 2013. The risk of marine bioinvasion caused by global shipping. Ecol. Lett. 16, 782-790. https://doi.org/10.1111/ele. 12111.

Sella, I., Perkol-Finkel, S., 2015. Blue is the new green - ecological enhancement of concrete based coastal and marine infrastructure. Ecol. Eng. 84, 260-272. https:// doi.org/10.1016/j.ecoleng.2015.09.016.

Sherrard, T.R., Hawkins, S.J., Barfield, P., Kitou, M., Bray, S., Osborne, P.E., 2016. Hidden biodiversity in cryptic habitats provided by porous coastal defence structures. Coast. Eng. 118, 12-20. https://doi.org/10.1016/j.coastaleng.2016.08.005.

Simberloff, D., 2005. Non-native species do threaten the natural environment!. J. Agric. Environ. Ethics 18, 595-607. https://doi.org/10.1007/s10806-005-2851-0.

Stachowicz, J.J., Whitlatch, R.B., Osman, R.W., 1999. Species diversity and invasion resistance in a marine ecosystem. Science 286, 1577-1579. https://doi.org/10.1126/ science.286.5444.1577.

Stark, J.S., 1998. Heavy metal pollution and macrobenthic assemblages in soft sediments in two Sydney estuaries, Australia. Mar. Freshw. Res. 49, 533-540. https://doi.org/ 10.1071/MF97188.

Statham, P.J., 2012. Nutrients in estuaries-an overview and the potential impacts of climate change. Sci. Total Environ. 434, 213-227. https://doi.org/10.1016/j. scitotenv.2011.09.088.

Strain, E.M., Olabarria, C., Mayer-Pinto, M., Cumbo, V., Morris, R.L., Bugnot, A.B., Dafforn, K.A., Heery, E., Firth, L.B., Brooks, P., Bishop, M.J., 2017. Eco-engineering urban infrastructure for marine and coastal biodiversity: which interventions have the greatest ecological benefit? J. Appl. Ecol. 55, 426-441. https://doi.org/10.1111/ 1365-2664.12961.

Strain, E., Alexander, K., Kienker, S., Morris, R., Jarvis, R., Coleman, R., Bollard, B., Firth, L., Knights, A., Grabowski, J., 2019a. Urban blue: a global analysis of the factors shaping people's perceptions of the marine environment and ecological engineering in harbours. Sci. Total Environ. 658, 1293-1305. https://doi.org/10.1016/j. scitotenv.2018.12.285.

Strain, E., Morris, R., Bishop, M., Tanner, E., Steinberg, P., Swearer, S., Macleod, C. Alexander, K., 2019b. Building blue infrastructure: assessing the key environmental issues and priority areas for ecological engineering initiatives in Australia's metropolitan embayments. J. Environ. Manag. 230, 488-496. https://doi.org/10.1016/ j.jenvman.2018.09.047.

Trannum, H.C., Olsgard, F., Skei, J.M., Indrehus, J., Øverås, S., Eriksen, J., 2004. Effects of copper, cadmium and contaminated harbour sediments on recolonisation of softbottom communities. J. Exp. Mar. Biol. Ecol. 310, 87-114.

Tyrrell, M.C., Byers, J.E., 2007. Do artificial substrates favor nonindigenous fouling species over native species? J. Exp. Mar. Biol. Ecol. 342, 54-60. https://doi.org/10. 1016/j.jembe.2006.10.014.

Valentine, P.C., Collie, J.S., Reid, R.N., Asch, R.G., Guida, V.G., Blackwood, D.S., 2007. The occurrence of the colonial ascidian Didemnum sp. on Georges Bank gravel habitat-ecological observations and potential effects on groundfish and scallop fisheries. J. Exp. Mar. Biol. Ecol. 342, 179-181. https://doi.org/10.1016/j.jembe.2006. 10.038 .

Vaselli, S., Bulleri, F., Benedetti-Cecchi, L., 2008. Hard coastal-defence structures as habitats for native and exotic rocky-bottom species. Mar. Environ. Res. 66, 395-403. https://doi.org/10.1016/j.marenvres.2008.06.002.

Wasson, K., Zabin, C.J., Bedinger, L., Diaz, M.C., Pearse, J.S., 2001. Biological invasions of estuaries without international shipping: the importance of intraregional transport. Biol. Conserv. 102, 143-153. https://doi.org/10.1016/S0006-3207(01)00098-2.

Whitehead, P., Wilby, R., Battarbee, R., Kernan, M., Wade, A.J., 2009. A review of the potential impacts of climate change on surface water quality. Hydrol. Sci. J. 54, 101-123. https://doi.org/10.1623/hysj.54.1.101.

Whitlatch, R.B., Zajac, R.N., 1985. Biotic interactions among estuarine infaunal opportunistic species. Mar. Ecol. Prog. Ser. 21, 299-311.

Wood, C.A., Bishop, J.D.D., Yunnie, A.L.E., 2015. Report to the Bromley Trust: RAS 2014 Non-native Species Rapid Assessment Surveys in English Marinas.

World Port Source, 2019. Available. http://www.worldportsource.com/, Accessed date: 9 May 2019.

Zaiko, A., Olenin, S., Daunys, D., Nalepa, T., 2007. Vulnerability of benthic habitats to the aquatic invasive species. Biol. Invasions 9 (6), 703-714.

Zardi, G.I., Nicastro, K.R., McQuaid, C.D., Rius, M., Porri, F., 2006. Hydrodynamic stress and habitat partitioning between indigenous (Perna perna) and invasive (Mytilus galloprovincialis) mussels: constraints of an evolutionary strategy. Mar. Biol. 150 (1), 79-88. https://doi.org/10.1007/s00227-006-0328-y. 